\title{
Mixing and Re-Purposing Realities
}

\author{
Tom Flint \\ Edinburgh Napier \\ Lynne Hall \\ University of \\ Sunderland \\ Fiona Stewart \\ Catherine O'Brien \\ University \\ Edinburgh Napier \\ Jupiter Artland \\ Edinburgh
}

\begin{abstract}
This paper discusses a mixed reality that intertwines two parallel spaces, a real and a virtual contemporary sculpture park. With the goal to create a game that motivated children to explore the park and engage with the artworks, we engaged with children as informants. We developed a cast of characters based on the children's input that lived in the sculpture park. Using the characters as inspiration we created a three-act narrative, with the canonical trajectory provided as a sequential clues treasure hunt. The clues are integrated into character dialogue, with traversal and transitions reinforced through the narrative. Although the narrative and game were designed for a collaborative, multi-user, multi-device experience, the characters, narrative and experience were rapidly re-purposed for an individual game on a mobile phone. This re-purposing focused on the transitions, using dramatic narrative to reinforce and mask reality change. Our results are positive, children enjoyed the mixed reality experiences and are keen to engage in different realities. Repurposing assets, such as characters and narratives as well as virtual spaces is effective, enabling rapid development of similar, yet very different mixed reality experiences.
\end{abstract}

Mixed Reality, Child-centred design, Minecraft, Character-based narratives, Games, Make-Believe

\section{INTRODUCTION}

As virtual, augmented and mixed reality technologies become ubiquitous, it has become increasingly important for museums and cultural institutions to exploit them in engaging children. Technology is well known as an attractor that can elicit engagement between children, museums and culture (Roussou, 2004) with a range of apps developed to improve the child visitor experience (Shrikant, 2017). Mixed Reality aims to exploit the contextual space between real and virtual environments offering new ways to participate and engage. Nintendo's Pokémon Go has firmly established the notion of a mixed reality experience for children (and adults) within the public sphere.

In this paper we discuss a mixed reality experience for 8-11-year olds at Jupiter Artland, a contemporary sculpture park on the outskirts of Edinburgh. Our intention is to increase the memorability of the visit and of the artworks potentially contributing to children having an increased awareness of contemporary art. Our research focus is on negotiating the space and transitions between realities, investigating this in tandem with children, creating experiences that reflect how children expect to engage across and within a continuum of realities. As outlined here, through engaging children as informants (Druin, 2002) we aimed to develop mixed reality experiences that facilitated children's desire to engage in both the real and virtual, and to manufacture a willingness in participants to readily transition from one reality to another.

\section{INFLUENCING PERSPECTIVES \& DESIGN DECISIONS}

For children to engage in both the real and virtual, the experience needs to be blended, with the digital and the real tightly aligned. Benyon (2012) notes that interaction and engagement must be designed with the blended space rather than designing for either the real space or the digital space individually and then considering the blend. Benyon aims to maximise the relationship between spaces (Benyon et al 2012), with his approach effectively used to create blended experiences in partnership with children in an outdoor museum (O'Keefe et al 2014)

For us, the beginning of the blend is the purpose of the engagement, in our case for children to visit and experience artworks. Although sculpture parks can be non-linear experiences where visitors can choose what and where to explore, children are often provided with a series of instructions gamified as an enjoyable activity such as a quiz or clue-based treasure hunt. Through providing this structure, particularly if sequential dependent clues are used, teachers and heritage providers are creating a canonical trajectory, that is the expected traversal of 
a participant through an experience as envisioned by the designer.

Benford et al (2009) highlight that a major challenge with the canonical trajectory in mixed reality experiences is simply to get the user to move location from one point to the next. Benford solves transition issues by using well placed orchestrators (human beings). In Fosh et al's (2015) mixed reality sculpture park experience, orchestration or the motivation to move was devolved to participants who were provided with images and prompted to seek out the sculptures. However, many successful children's games use the approach of 'find and collect' particularly in the roleplay genre, where there is little challenge in encouraging participants to move on to the next location and next piece of treasure. In some situations, this is because of the desire to finish and 'win' as quickly as possible. However, in others, this desire is supported by an underpinning storyworld, with an alternative approach to providing a canonical trajectory achieved using narrative and storytelling.

The human ability to employ imagination to 'act as though' or pretend something is real when it is not, be that setting, object or premise, is widely exploited in fiction, theatre, films and games. Pretending is a skill developed in childhood and is an important part of the ability to play (Walton, 1990). Winnicot (1982) argues that play is how we begin to negotiate the reality of objects that are separate from our own body discussing the ability for what he calls fantasaying where we are able to imagine directly experiencing certain events whilst in reality these events are not occurring. This ability to pretend is a key characteristic for mixed reality, relying on participants' ability to accept a duality of that presented to them by the virtual simultaneously with the real world.

The active participation of the player within a narrative is typical of games storyworlds, with player actions impacting on outcome. This narrative underpinning provides a mechanism to aid participants in the pretence required for mixed reality. This approach has been infrequently used in mixed reality, although successful experiences, such as The Beast, an Alternate Reality Game used to promote the film Al (Örnerbring, 2007) and the play Frogman (Curious Directive, 2018) highlight the potential of this approach.

Our challenge was to create a game that supported the user in pretending that an experience in loosely coupled virtual space is of value, as important, and perhaps, as real, as that occurring in the physical space. Turner and her colleagues (Turner et al 2016) discuss the transference between the real and the virtual as an act of decoupling from one and coupling into the other. They highlight the potential and benefits of allowing the user to 'fill in the gaps,' as they transition into loosely coupled or nonrealistic virtual spaces in mixed reality experiences. Extending this, we can also anticipate that users will fill in gaps that emerge in real space, for example, maintaining belief and participating in a story that may be predominantly happening in a virtual space.

From these influencing perspectives, our blend for our mixed reality experience at Jupiter Artland aimed to motivate users to engage: 1) By gamifying the experience, using an approach known to work in both the real and virtual to stimulate exploration (a treasure hunt); 2) Through underpinning the experience and facilitating pretence through a narrative and participatory storyworld approach; and 3) By requiring transitions as part of both narrative and game

\section{INGREDIENTS}

In developing our mixed reality experience, we had three main ingredients, the real Jupiter Artland, its virtual twin and our class of child informants.

Jupiter Artland is a sculpture park that displays realised commissioned proposals from invited artists. Artworks are typically large scale and aim to have a significant impact on visitors. For example, in figure 1, Charles Jencks' Cells of Life, there are 3 people on the central path highlighting the size of the artwork. Artists spend time in Jupiter Artland and produce work specifically for a chosen space within the grounds. Thus, it is not simply the sculptures that are significant but also their placement within the landscape and in relation to each other.

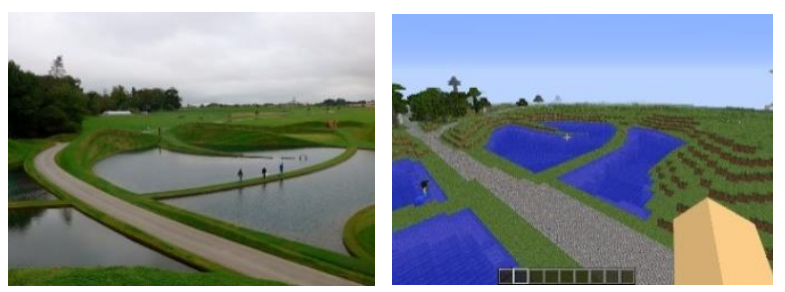

Figure 1. Cells of Life at Jupiter Artland, real and virtual

Although many mixed realities partially augment the real with additional information and experience, in our case, we had a facsimile, developed to enable remote communities to have an experience of Jupiter Artland. Our virtual Jupiter Artland is a complete, geographically accurate, to scale version of Jupiter Artland and its artworks constructed in Minecraft. This was developed for use in Jupiter Artland's outreach work with remote communities. Our goal now was to use virtual Jupiter Artland, in situ at Jupiter Artland, to create an engaging and memorable experience that mixed the real and virtual, providing two parallel but interconnected realities 
Table 1: Informant Activities for our Mixed Reality Experience

\begin{tabular}{|c|c|c|}
\hline Purpose & Experience & Outputs \\
\hline $\begin{array}{l}\text { To gain children's } \\
\text { perspectives on virtual Jupiter } \\
\text { Artland. }\end{array}$ & $\begin{array}{l}\text { Free-range and directed exploration. with Virtual Jupiter } \\
\text { Artland for } 2 \text { hours in pairs in the classroom. }\end{array}$ & $\begin{array}{l}\text { Children's feedback and } \\
\text { recommendations informed } \\
\text { design of VJA V2 }\end{array}$ \\
\hline $\begin{array}{l}\text { To gauge interest and } \\
\text { relevance of a storyworld } \\
\text { approach. }\end{array}$ & $\begin{array}{l}\text { Class-based discussion of creating a game in virtual } \\
\text { Jupiter Artland and what the experience might involve. }\end{array}$ & $\begin{array}{l}\text { Children's interest assessed, } \\
\text { recommendations and } \\
\text { suggestions provided. }\end{array}$ \\
\hline $\begin{array}{l}\text { To develop the population of } \\
\text { the storyworld for JA. }\end{array}$ & $\begin{array}{l}\text { Homework task to produce characters that live in virtual } \\
\text { Jupiter Artland through providing drawings and stories. }\end{array}$ & $\begin{array}{l}\text { Design and back story for } \\
\text { characters informed by the } \\
\text { children. }\end{array}$ \\
\hline $\begin{array}{l}\text { To formatively evaluate the } \\
\text { mixed reality game. }\end{array}$ & $\begin{array}{l}\text { Children engaged with the Mixed Reality experience at } \\
\text { Jupiter Artland. The children were asked to test the } \\
\text { game to make sure it was an enjoyable experience. }\end{array}$ & $\begin{array}{l}\text { Game play tested and } \\
\text { evaluated. }\end{array}$ \\
\hline $\begin{array}{l}\text { To assess children's views of } \\
\text { informing the game }\end{array}$ & $\begin{array}{l}\text { Children discussed the game informally at Jupiter } \\
\text { Artland. They were asked whether they felt that they had } \\
\text { an input to the game. They were also asked whether the } \\
\text { narrative was evident in the experience. }\end{array}$ & $\begin{array}{l}\text { Children's views of the game } \\
\text { and of their contribution to it. }\end{array}$ \\
\hline $\begin{array}{l}\text { To provide character } \\
\text { recordings }\end{array}$ & The children selected characters and read the dialogue. & Audio for Android version. \\
\hline $\begin{array}{l}\text { To perform a summative } \\
\text { evaluation of the mixed reality } \\
\text { game. }\end{array}$ & $\begin{array}{l}\text { Children used the mixed reality game to locate clues and } \\
\text { characters. They completed a short questionnaire and } \\
\text { participated in a class discussion. }\end{array}$ & $\begin{array}{l}\text { Children's view of the game } \\
\text { and their contribution }\end{array}$ \\
\hline
\end{tabular}

In developing our experiences, we have engaged with the same class of 20 children (10 boys and 10 girls - aged 8-9 at start) over three years to inform and contribute to our work. Our approach and methods were designed for the constraint of repeated, but infrequent, limited access to our class. Table 1 briefly outlines the activities used to inform the mixed reality experience, with these discussed below.

Before we met the class, they had already visited Jupiter Artland. In our first session, they interacted for 2 hours with virtual Jupiter Artland. From observation and discussion, we could gather that the children enjoyed this experience. Feedback varied from improving artwork graphics, to including rollercoasters, portals and fighting zones. Version 2 of virtual Jupiter Artland developed in response to the feedback was used for the mixed reality experience detailed here.

\section{CREATING THE CAST}

As evidenced by children's media, children in the 911 age group are interested in creatures, characters, adventure and pretence. Alternative, near realities are a highly engaging concept for children, demonstrated by the popularity of the magical and muggle parallel worlds in Harry Potter; or the gyms of Nintendo's Pokémon Go. Children are keen to develop narratives about characters, with writing, making-up and enjoying stories part of many children's school and recreational activity. In collaboration with the teacher of our informant class and Jupiter Artland's educational team, we decided to develop a character-based narrative, built on the basic plot of someone or something other than us living in virtual Jupiter Artland.

In discussing a suitable theme for the characters, we decided on using traditional creatures from Scottish mythology. This not only mapped well with the literacy, history and cultural curricula for the children, but is also fun, imaginative and of interest to most children. In some ways, it also questions reality, are fairies, hags and boggles real or not? However, as children are already encouraged to pretend that such mythological folkloric characters might exist, an easy pretence is that they live in Minecraft.

After interacting with virtual Jupiter Artland, the children were told that we were creating a game using virtual Jupiter Artland and that we would like to theme the game around mythical creatures from Scottish tales. As a homework task the children were asked to participate in creating Minecraft versions of the characters for this game.

The children were positive and interested in this homework task and expressed considerable interest in a mixed reality game. During discussions, our class emphasised the potential of Minecraft to enhance the Jupiter Artland experience. For example, flying not only offers rapid traversal between artworks but provides aerial views.

For their homework, each child was given a bound printed booklet that described and provided pictures of mythological characters such as Brownies, Glaistig, Kelpies and Selkies. They were provided with examples of Minecraft drawings, see figure 2, and with squared paper to draw their own Minecraft character. They were also asked to provide a story for their character, where the character lived; what they 
did; how they get on with other characters. They were told that we would develop their character ideas in our game and then return for feedback.

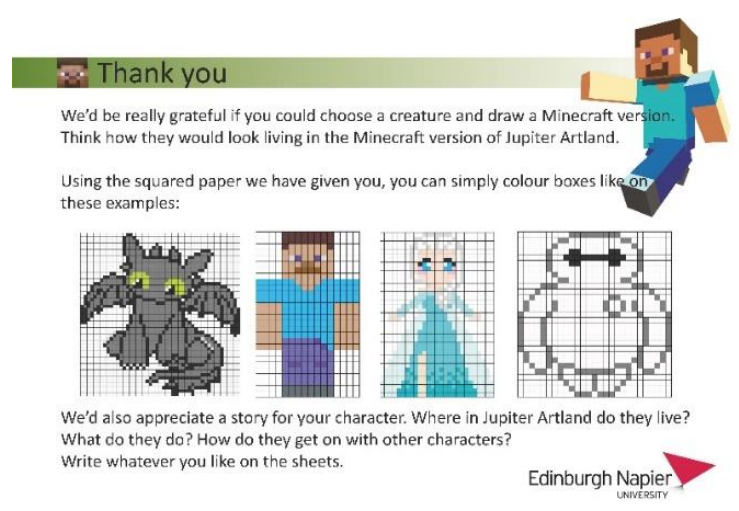

Figure 2 Booklet provided to children

The children's character ideas were developed over the next week. They were then gathered by the teacher and provided to the researchers.

\section{OUR CAST, THE CHILDREN'S CHARACTERS}

Our approach to narrative development was firstly to focus on who might live in Jupiter Artland and then to establish the story and plot using these characters, based on the children's ideas. In populating virtual Jupiter Artland, our intention was to include as many of the children's characters as possible. Jupiter Artland is vast, with a plethora of artworks across a large park so there is plenty of space for 20 characters, and indeed many more. All of the children completed the homework task.

We reviewed the homework entries to develop the visualisations and character synopses highlighting where characters might live, their interests, friends, etc. We had intended to incorporate one character per child, but after review, this resulted in 9 characters, see table 2. This reduction resulted from some submissions that exactly replicated the provided booklet. We also had multiple entries for some characters and combined these. For example, the Kelpie had its physical shape adopted from one entry, its colour scheme from another and from the third that the Kelpie should live in the duck pond and be friends with Cailleach Bheur. For Cait Sith, we adopted the visuals of one entry and the description from another.

Six of the children's visual drawings were directly reproduced including Cailleach Bheur (see figure 3) and Brian (see figure 4). With some drawings children had misunderstood the principle of using squares to make up an image. We adapted these images or simply employed the character descriptions to help with our character appearance. We also extended and amended the children's ideas. For example, one child proposed that Cailleach Bheur, see figure 3, lived in the Stone House, stating that she was evil and enjoyed killing people.

Table 2 Characters from Homework Task

\begin{tabular}{|c|c|c|c|c|}
\hline Character & Children's suggestions & \multicolumn{2}{|c|}{ Diamond } & Location \\
\hline $\begin{array}{l}\text { Cu Sith } \\
3 \text { entries }\end{array}$ & $\begin{array}{l}\text { Old, wise, large, green fairy dog. Kind, protective. } \\
\text { Others listen to him. Difficult to find. Friendly but can } \\
\text { bite. Lives on hills in Cells of Life }\end{array}$ & $\begin{array}{l}\text { Kind } \\
\text { Wise }\end{array}$ & $\begin{array}{l}\text { Hoary } \\
\text { Patient }\end{array}$ & $\begin{array}{l}\text { Wooded area } \\
\text { Cells of Life suggested } \\
\text { but over populated }\end{array}$ \\
\hline $\begin{array}{l}\text { Kelpie } \\
3 \text { entries }\end{array}$ & $\begin{array}{l}\text { Water horse likes to run through meadows. Not very } \\
\text { trusting, Dangerous. Friend of Cailleach Bheur. Lives } \\
\text { at Duck Pond }\end{array}$ & $\begin{array}{l}\text { Proud } \\
\text { Wild }\end{array}$ & $\begin{array}{l}\text { Impulsive } \\
\text { Expressive }\end{array}$ & $\begin{array}{l}\text { Duck Pond } \\
\text { Suggested by child }\end{array}$ \\
\hline $\begin{array}{l}\text { Cailleach } \\
\text { Bheur } \\
2 \text { entries }\end{array}$ & $\begin{array}{l}\text { Wise, dangerous, hag. Can control weather. Enjoys } \\
\text { watching humans die and death (but not causing it). } \\
\text { Lives in Stone House. Known as Blue Witch. }\end{array}$ & $\begin{array}{l}\text { Lonely; } \\
\text { Bitter }\end{array}$ & $\begin{array}{l}\text { Revengeful } \\
\text { Ashamed }\end{array}$ & $\begin{array}{l}\text { In Memory } \\
\text { Stone House suggested } \\
\text { In Memory fits character } \\
\text { better }\end{array}$ \\
\hline $\begin{array}{l}\text { Selkies } \\
2 \text { entries }\end{array}$ & $\begin{array}{l}\text { Lives in water. Runs from humans, Likes fish. Kind, } \\
\text { gentle and very shy. Friends with Caesg (mermaid) }\end{array}$ & $\begin{array}{l}\text { Kind } \\
\text { Shy }\end{array}$ & $\begin{array}{l}\text { Reasonable } \\
\text { Empathetic }\end{array}$ & $\begin{array}{l}\text { Cells of Life } \\
\text { Suggested by child }\end{array}$ \\
\hline $\begin{array}{l}\text { Cait Sith } \\
2 \text { entries }\end{array}$ & $\begin{array}{l}\text { Black Cat Lives in Crystal Caves (Light Pours Out Of } \\
\text { me] where he takes out jewels from the wall. Eats fish } \\
\text { from windy hills }\end{array}$ & $\begin{array}{l}\text { Friendly } \\
\text { Clever }\end{array}$ & $\begin{array}{l}\text { Relaxed } \\
\text { Egotistic }\end{array}$ & $\begin{array}{l}\text { Light Pours Out of me } \\
\text { Suggested by child }\end{array}$ \\
\hline $\begin{array}{l}\text { Caesg } \\
2 \text { entries }\end{array}$ & $\begin{array}{l}\text { Mermaid. Can grant } 3 \text { wishes Sometimes drowns } \\
\text { people. Lives in seas, swamps and lakes. } \\
\text { Unpredictable and may be nice or not. }\end{array}$ & $\begin{array}{l}\text { Protective } \\
\text { Tricky }\end{array}$ & $\begin{array}{l}\text { Mysterious } \\
\text { Suspicious }\end{array}$ & $\begin{array}{l}\text { Cells of Life } \\
\text { No specific location } \\
\text { except water }\end{array}$ \\
\hline $\begin{array}{l}\text { Brownie } \\
1 \text { entry }\end{array}$ & $\begin{array}{l}\text { Helps around house. Lives in caves and holes. Mostly } \\
\text { friendly can be defensive and dangerous. Kind to } \\
\text { animals and people. }\end{array}$ & $\begin{array}{l}\text { Naïve } \\
\text { Helpful }\end{array}$ & $\begin{array}{l}\text { Indecisive } \\
\text { Empathetic }\end{array}$ & $\begin{array}{l}\text { Suck } \\
\text { No specific location but } \\
\text { Suck is a deep hole }\end{array}$ \\
\hline $\begin{array}{l}\text { Glaistig } \\
1 \text { entry }\end{array}$ & $\begin{array}{l}\text { Half-goat, half-human, likes climbing on rocks. Lives in } \\
\text { the Stone House - likes the rocky floor. }\end{array}$ & $\begin{array}{l}\text { Careless } \\
\text { Brave }\end{array}$ & $\begin{array}{l}\text { Outgoing } \\
\text { Cheerful }\end{array}$ & $\begin{array}{l}\text { Stone House } \\
\text { Suggested by child }\end{array}$ \\
\hline $\begin{array}{l}\text { Brian } \\
1 \text { entry }\end{array}$ & $\begin{array}{l}\text { Super evil hero. No weaknesses. Lives in tree houses } \\
\text { so he can see everything. Destroys anything in his } \\
\text { path }\end{array}$ & $\begin{array}{l}\text { Clever } \\
\text { Brutal }\end{array}$ & $\begin{array}{l}\text { Greedy } \\
\text { Calculating }\end{array}$ & $\begin{array}{l}\text { Tree House } \\
\text { Suggested by child }\end{array}$ \\
\hline
\end{tabular}


We developed this character as one who was interested in death. The child's suggested location of the Stone House was already occupied by Glaistig, a half human half goat character. The pupil who proposed Glaistig's location argued that she should live in Stone House because "goats like climbing on rocks." Stone House has no floor and frames the exposed bedrock meaning the floor is rocky and uneven. This means that Glaistig's attraction to Stone House not only made logical sense but was contextually relevant to the artwork. We made the decision to place Cailleach Bheur within the art piece In Memory, a reconstructed set of graves
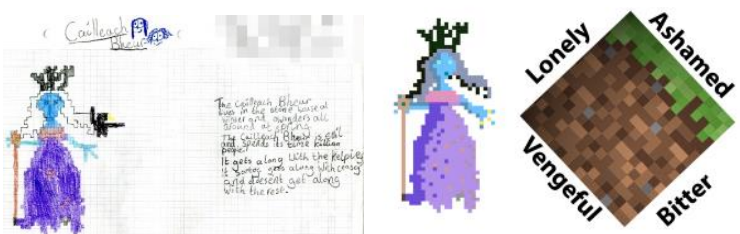

Synopsis. Cailleach Bheur is a wise and very ancient hag who is capable of controlling weather. She lives at In Memory because she enjoys death and the passing of people. She has a strong relationship with the Kelpies and has respect for $\mathrm{Cu}$ Sith because of his age and power. Cailleach Bheur can be very dangerous as she enjoys watching humans die. This is not malevolent, she simply has a completely different concept of what death might mean and does not think humans are important.

Figure 3 Cailleach Bheur: child's entry, in Minecraft, her character diamond and synopsis

We used Freeman's character diamonds (Freeman, 2004) to support narrative construction. This toplevel method of detailing a character's behaviour and driving motivations provides a practical tool for rapid story development, often used in the creation of game narratives enabling a diversity of characters to participate in a rich storyworld. Character diamonds highlight key traits and characteristics aiming to create insight into the type of role that a character might undertake in a narrative. Each of the character's appearance, location and key traits were developed from the homework entries, providing a cast and inspiration for narrative development.

\section{OUR PLOT, USING THE CHARACTERS}

The next focus was how we could use the characters to create a story that encouraged the children to explore and engage with both the real and virtual Jupiter Artland. To this end we hoped to create an experience that supported the act of pretending or make-believe play. We have already argued that it is useful to exploit the ability to pretend, however pretending has limits (Turner et al 2015) . The imperative is to create experiences where participants are motivated and want to play along.

In their homework, the majority of the characters the children described were dangerous and might either eat or kill humans in a range of ways. This dark view suggested that our story should have a plot underpinned by danger. With this in mind, we used one character that had been created without expectation - Super Hero Evil Brian, see figure 4.

Brian had a strong story, he lives in tree houses, doesn't have a weakness, etc. Thus, rather than reject this difficult, slightly out-of-scope antagonistic character, it was felt that this was an unanticipated opportunity and we decided to make Brian the central antagonist of the story.

By making Brian a central character in the story, we embraced the creative efforts of informants. We discovered later that there is a popular meme within the Minecraft community of a character named Herobrine. The Herobrine character is treated as a mythological destructive character, thus, rather than our initially perceived view that the story might be related to myths, in response to our informants it developed more similarities with superhero characters and draws directly from Minecraft folklore.
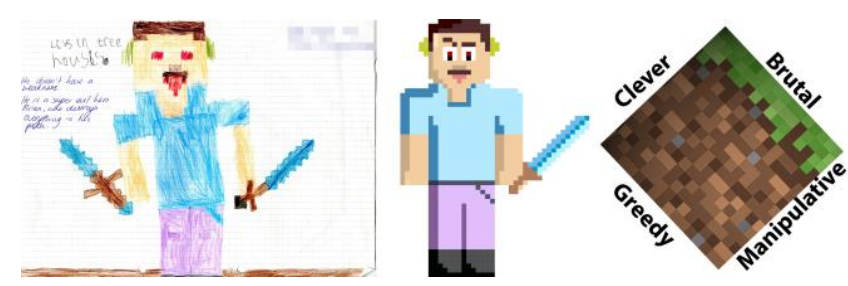

Figure 4 Brian: participant's submission; as he appeared in Minecraft; and his character diamond.

Gaining audience cooperation relates to their willingness to engage in the pretence, to cooperatively pretend that the sets are real, the characters' concerns matter and so on. Dramatic licence uses both our ability to pretend and scaffolds the audience in engaging in pretence. The false premise, and a complicit audience, willing to believe something untrue or unreal (Davis, 2005) is essential for mixed reality experiences.

In discussions with our informant class, it was apparent that children wanted a game with drama, action and clear player goals and needs, like other media they engage with. If it wasn't real, it needed to give a sense of credibility, with children happy for us to use dramatic licence and device, to invent, extend and require make believe and play.

In determining the structure of the story, we looked to Field (1982) who introduces the 'paradigm' tool for structuring the narrative of a story into three acts: set up confrontation and resolution, see figure 5 . The 
structure of the narrative is designed to create rising tension which eventually gets resolved at the end of act 3. Each act is initiated as a plot point or periods in a story where the protagonist's world view is significantly altered. For our mixed reality experience our aim was to take this somewhat literally and actually change the player's world at the plot points. Our class teacher agreed that the three-act paradigm approach provided a useful, comprehensible structure that children would understand and engage with.

In our game, we decided to plot our story and scaffold belief by casting our super-villain, Brian, as the antagonist of our experience, see figures 5 and 6. Super-villains regularly appear in media, games and stories for 8-11-year-old children. Plots are often stereotypical, with scripts following well-understood and engaging tropes and story arcs. Brian would provide the dramatic element of our narrative. However, where there is a villain there is also the 'good guy.' Whilst to some degree in the game context this is the children, we also provided a character who supports the children in their quest, helping them to negotiate with the 'dangerous' creatures in the park. Brownie was selected for this role, with his character traits of Naïve, Helpful, Indecisive and Empathetic. In particular Brownie likes to help people and animals, so naturally would want to help the children. Also, Brownie lives in Suck (a deep hole), very near to the woodland classroom where we would begin our experience, and so would be easy to find.

In the homework and discussions children regularly renamed artworks. The renaming was typically descriptive focusing on key features of the artwork, for example Cells of Life became the Green Hills and the Windy Hills. The Light That Pours Out of Me, constructed from amethyst, was renamed the Crystal Cave. We adopted these names, with the view that it makes sense that creatures might have their own names for the different works.

\section{TRAJECTORY AND TRANSITION}

Our characters lived in artworks in two areas, the woodlands (Act 2 First Half) and the Green Hills (Act 2 Second Half). Act 1 and the resolution were in the woodland classroom located in-between these two areas. The geography of Jupiter Artland lends itself to this structured narrative with a concentration of works in these areas.

Our canonical trajectory began in the woodland classroom and was underpinned at a basic level by a sequential clues treasure hunt that would motivate children to visit different locations. In blending the mixed reality, finding the clues would require collaboration between children located separately in the different realities. This collaboration would be essential for success, with some interactions only possible in the real Jupiter Artland and others in the virtual.

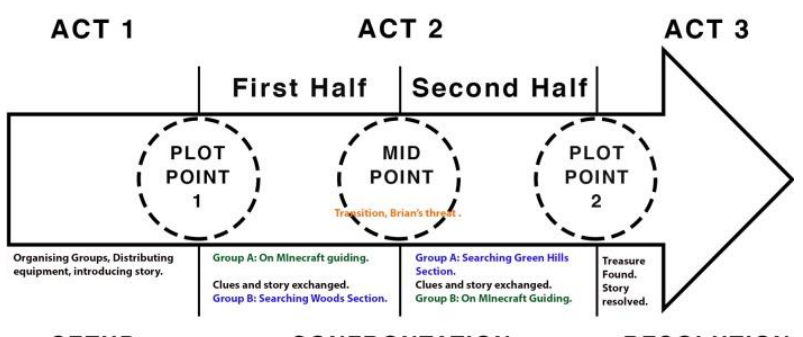

SETUP

CONFRONTATION

RESOLUTION

Figure 5 Narrative structure based on Field's paradigm

Act 1: Introduction and Set-Up

Opening Narrative

The creatures in virtual Jupiter Artland had lived in harmony with humans around Jupiter Artland for years until a flood happened. A human named Brian told the other humans that the creatures had caused the flood and acted as negotiator between the creatures and the humans. But, the truth was that Brian had caused the flood to gain this central position and he used his role to keep the creatures in check and steal the magical gold the creatures used to navigate between the virtual and real Jupiter Artland.

Plot Point 1: Looking for Clues

The children were told that their mission was to find a friendly creature called Brownie, then help him negotiate with the creatures to discover what was happening and where the gold is hidden, so that the creatures could once again travel at will between the Minecraft world and Jupiter Artland.

Act 2: First Half Finding the Clues - Woodland

Children work collaboratively in both realities, locating the various clues and engaging with the characters.

Mid-Point: Brian's Threat

Once all the clues in Act 2 First Half are collected, Brian 'hacks' into the tablet and informs the children in Jupiter Artland that he can see them; that he knows what they're doing; and threatens them. The only solution (suggested by Brownie) is for the children in the Park to exchange roles with those on Minecraft so that they can find the gold.

Act 2: Second Half Finding the Clues -Green Hills

Children again collaboratively locate clues, however, now there is more tension, with the fear that Brian will realise that different children are looking for clues.

Act 3: Clues and Resolution: Green Hills

Once they have all the clues the children return to the woodland classroom.

Plot Point 2: Unlocking the pathways and resolution Once all clues are located, the experience ends with the pathways open once again and Brian confined to the Tree House. The children receive a letter from Brownie thanking them for their help.

\section{Figure 6: Three act structure}

Half of the class would search the real world for clues. These were provided in physical treasure boxes, at the locations where the characters lived. 
Each treasure box contained a laminated password which would unlock dialogue in a tablet application, see figure 8 . In the woodland classroom, half of the class were in virtual Jupiter Artland, see figure 7, able to see digital beacons placed in the exact relative location of the clues in the real world. Communicating via walkie talkie the virtual players would guide the participants to the real-world treasure.

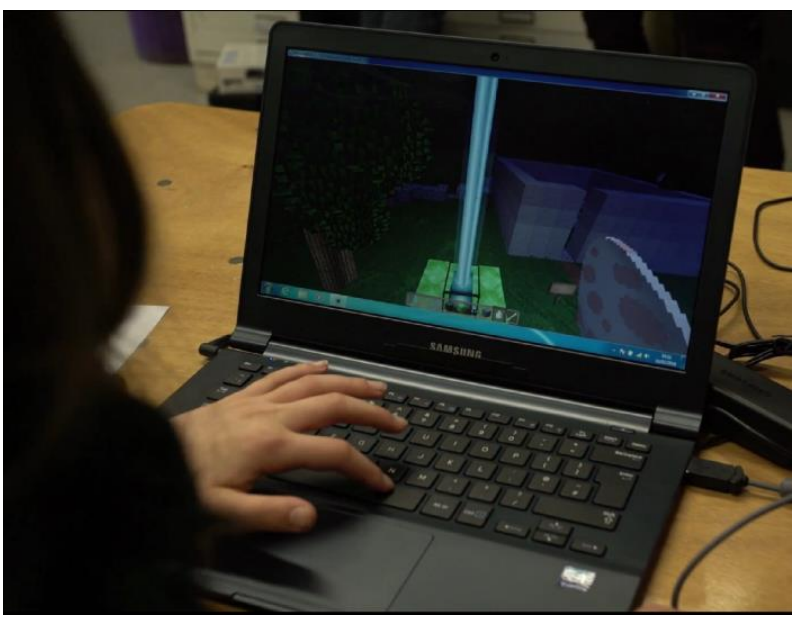

Figure 7 Minecraft view of the location of the treasure box in the real world

Clues to the next location were provided during the interaction with characters and were summarised on screen after the character had 'spoken'. The dialogue would reveal the location of the next clue. The characters would also provide narrative prompts to encourage children to go from one location to the next. Taking advantage of their ability to fly to the next location, the children in the virtual world could then locate the treasure box before the children in the real world got there and help guide them.

In the dialogue between Kelpie and Brownie (figure $8)$, along with reinforcing the plot (Brian as villain) and highlighting Kelpie's characteristics (suspicious, dangerous) the next location, Cait Sith at The Light Pours Out of Me, is given. A prompt to leave is provided by the Kelpie swimming away.

In this mixed reality game all children would experience both the virtual and real Jupiter Artland, both guiding and being guided. Such role transition, from virtual to real and vice versa is highlighted by Benford as the situation where the continuity of an experience is most at risk. In order to facilitate swapping groups from searching in the real world to searching on Minecraft we included this as part of the narrative, aiming to smooth the transition (Benford et al., 2009).

In our narrative, the major transitions from real to virtual Jupiter Artland are at the plot points. The first transition is a response to find and help Brownie at plot point 1. During the second act, the children learn how to work together remotely and develop familiarity with the narrative, meeting the characters in the park. Rather than simply instruct the children to swap groups for the second area, we brought this into the narrative and made it seem that Brian had hacked the tablet application and warned them that he had been watching them and knew what they looked like. This meant that there was an imperative to swap groups for children Brian had not seen before.

Kelpie: Well, well, who do I see again. And some humans sneaking with you.

Brownie: Kelpie, I know you don't like visitors, especially our kind. But this is important. It looks like Brain lied to us and to people. He has hidden the magical gold and trapped us in the real world.

Kelpie: What do you mean?! He betrayed all of us? I can't trust any humans. I will find him and them.

Brownie: Calm down, we need a plan to find the gold. Tell me, have you seen him here recently? Anything suspicious?

Kelpie: Yes, he was sneaking around somewhere here. I think somewhere close to the Crystal Cave. You should talk to Cait Sith, he likes shiny things after all. Check out next to Crystal Cave, or how people like to call it, The Lights Pours Out of Me. That annoying Cait Sith, I can't think about this anymore. I need a swim.

Brownie: Kelpie, wait! Oh he's gone. Oh well, maybe the others will tell us more.

Figure 8: Brownie and Kelpie's dialogue

This requirement to change reality is achieved in the mid plot point in our 3-act structure, with a major shift for the children. At this point, a significant false premise is presented to the children, that Brian, who had so far been absent was back and this put some of them (those in Jupiter Artland) in danger. In Act 3, there is more urgency and requirement to find the clues, as Brian may discover the children are still engaged in the game. However, he doesn't, and the game is successfully resolved at the end of Act 3.

\section{FORMATIVE EVALUATION OF THE MIXED REALITY GAME}

Our informant class came to Jupiter Artland to engage with our mixed reality game. Equipment (e.g. tablets,walkie-talkies,laptops) were distributed, the class were split into groups of four and pairs within the groups were formed. The children were given a brief verbal introduction to the day (two game sessions with a lunch break) and Act 1 began.

Our informant class reacted positively from the start and were keen to engage and get going. Following our canonical trajectory, the children entered the different realities and wholeheartedly bought into the game. The transitions were readily accepted 
and there was no resistance to changing role from real to virtual and vice versa. The children responded positively to the characters and were interested in what they looked like and said. Discussion over lunch was excited and it was evident that the children followed the story rather than rushing from point to point in pursuit of treasure. In discussions, it became clear that all participants were aware of the narrative and were participating in make-believe, discussing Brian, Brownie and the characters they'd met. They were looking forward to the afternoon and looking forward to finding the gold and outsmarting Brian.

The event ended with the prize of some gold chocolate eggs and recognition from Brownie. Children were very positive about the whole experience. They had helped the creatures and overcome the villain. Unsurprisingly, suggested improvements included directly fighting and capturing Brian, who, in our narrative was simply locked in a Tree House. However, this simple narrative was highly effective, with all children engaged throughout the day.

We evaluated the mixed reality game with our informant class at Jupiter Artland. We observed the experience and gathered data using a short closedquestion, Likert scale rated questionnaire. This asked children if they felt that the characters were real; if the children found it easy to pretend the characters were in their world; if they could makebelieve that they were in the character's world; and if their work appeared in the game. The results were positive (see figures below), with our child informants significantly enjoying the game and feeling that they had made a significant contribution to it. 15 of our informant children (75\%) felt that their work had appeared in the game.

The data from our informant class have previously been presented (Flint et al 2016) but are repeated here to afford comparison with evaluations undertaken with two other groups of children. These were individuals attending Jupiter Artland as part of Edinburgh International Science Festival. The children interacted with the mixed reality game in organised sessions using the same equipment. We used the same questionnaire, without the question "I felt as though my work appeared in the game."

\subsection{Brief Results}

All of the participating children clearly enjoyed the mixed reality game, cooperating with the pretence, finding the treasure and playing along with the story. Children were significantly engaged with the mixed reality, engaging with characters and exploring the park. Children were successful in completing the quest, finding all the characters and clues. As with the previous experience the children were engaged by the narrative eager to find characters who could tell them more.

\section{I felt as though the characters were real}

Our informant class found the characters to be more real than those who had simply met the characters in the game. All but 2 of the informant children felt that the characters were at least somewhat real. For the players (those children attending the Science Festival), the realness was less convincing with several children strongly feeling that the characters were not real. More children felt that the characters were more real than not, however, the impact of having engaged in the design is significant, with the characters more real to their creators than to players.

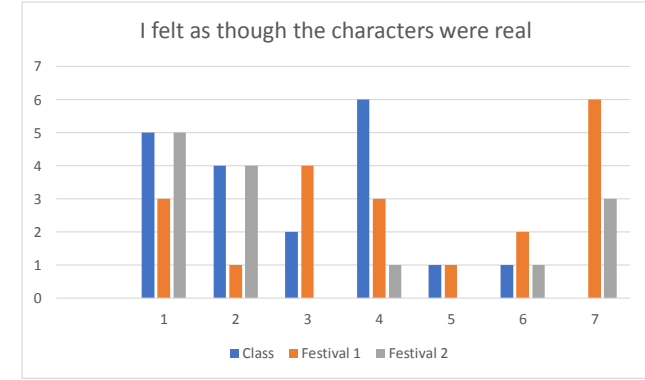

I found it easy to pretend the characters were in my world.

There is relatively little difference between the informants and the players, all were able to engage in the pretence, bringing make-believe into their world and participating in the narrative.

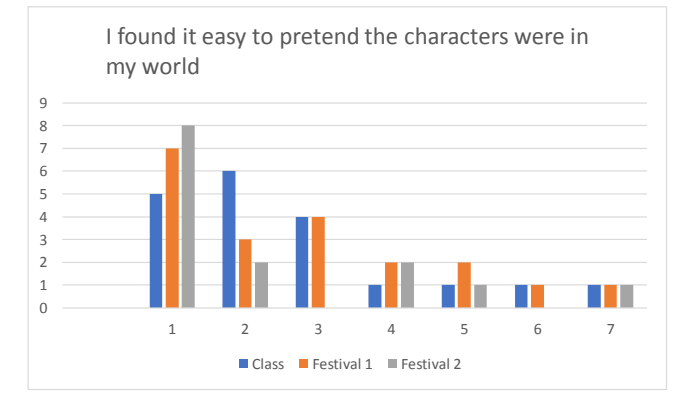

I felt I was in the characters' world

Most of the children felt to some extent that they were in the characters' world. This was particularly true of the players, who felt this more strongly than the informants.

I felt I was in the characters' world

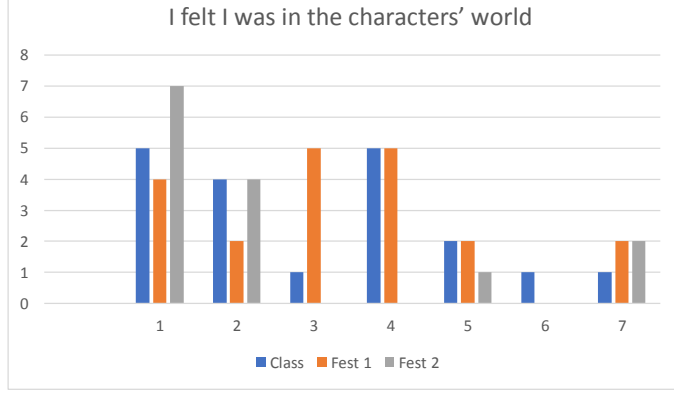


Children were more willing to place themselves conceptually into the characters' world than to feel that the characters were real.

\section{RE-PURPOSING THE MIXED REALITY}

Although, the game and narrative we had devised works well for class-based visits, the goal now became to re-purpose our game to be played by a single child on everyday technology such as a smart phone, for use by the public rather than as part of a class visit. Whilst, there was much we could re-use, this change in interaction approach had a significant impact on the blend of realities needed.

The mobile game required that the virtual reality was experienced individually whilst the child was in the park. The interaction approach devised to support collaboration and to reinforce the sense of being in two realities in the mixed reality game needed to be replaced. Now, rather than our transitions between realities being abrupt and critical, reinforced by plot and the child's role, they would instead need to be blended supporting a single role with episodes of engagement with different characters.

The sequential clue-based treasure hunt had been effective, with children readily understanding that when a character tells you to go somewhere to find something out, you do. However, the approach to unlocking the clues via a physical treasure box was limited requiring an automated solution. In response, the unlocking passwords were replaced by GPS signals, thus when the child arrived at a location, the character would use a signature phrase to gain the child's attention.

We had a significant change in our canonical trajectory, with one of our key locations, the woodland classroom, not available to the general public. In addition, as our mixed reality game had been devised to be near the woodland classroom, our trajectory had not included crossing the central area of the park, where Mark Quinn's Love Bomb, a major piece at Jupiter Artland is located. Resolution happens at Love Bomb in the mobile game.

Our original three act narrative, with the super-villain Brian, the helpful Brownie and the slightly dangerous fantastical characters, was compelling. The characters had engaged our informant children and the motivation to help Brownie find missing gold was sufficient to support the children in the pretence required for our mixed reality. Using Brian as a motivator, knowing there is a villain in the story works effectively as a driver. This need to complete the quest before super-villain, Brian, might catch them again had been sufficient to maintain pretence.

In the mobile game, we used a similar plot, with Brian still the potential threat, but without the need to change reality, instead there is the sense that Brian is looking for you and danger lurks. In Act 1, the setup, the child is sent a message from Brownie to come and find him at Suck. This interaction provides the child with the opening narrative, with Brownie asking the child to help him find where the gold is. Act 2 First Half as in the original, occurs in the woodlands, with the confrontation in the lower part of the park. The player suddenly receives messages (in the app) and discovers that Brian knows they are trying to help the creatures. In the mixed reality game, this was sufficient to motivate the children to believe in Brian, and to readily change reality. Here again, the goal was to find all the characters (and clues) before Brian found them. This dramatic urgency was reinforced with additions to some character scripts with the child eventually arriving in Act 3 , to the resolution at Love Bomb. On completing their quest, children receive an in-app token for a physical badge.

With the interaction focused on a mobile device, the transitions were significantly different to those in the previous game. Here, as in Pokemon Go, the transitions are within the same world, itself composed of two realities. However, one thing we want to avoid is children walking around Jupiter Artland staring at a screen. We aimed to avoid this with some character dialogues only possible where the characters are located. Keeping the phone in sleep mode was reinforced in the narrative as this enabled the creatures to talk to you (with audio alerts requiring the phone to be in sleep mode). Additionally, the phone in sleep mode meant that Brian could not find you.

To make the dialogues more interesting, we provided audio as well as text, returning to our informant class to voice their characters. Each character also recorded a signature phrase that was played when their GPS position was triggered. For example, when you find the mermaid she says, "Come with me, come swim with me."

\section{DISCUSSION}

With significant focus on the digitisation and virtualisation of cultural assets (European Commission, 2016) increasingly the designers of mixed reality experiences will be integrating existing digital assets with the real. Thus, the blend needs to consider how existing digital assets can support the coupling and alignment between real and virtual. In considering how existing assets could be used, we explored the use of virtual Jupiter Artland for mixed reality experiences for children.

We engaged with children as informants. Whilst access to our informant class was relatively limited, they provided valuable input and feedback. Taking a character-based approach to constructing a narrative, we created a cast of characters based on 
the children's content, that would inspire our story. Using a mixture of approaches including classroombased activities coupled with homework was effective and significantly influenced our narrative. We designed experiences that children, both our informants and those who only experienced the game, enjoyed and readily engaged in.

In creating both the mixed reality and the mobile game, we aimed to create a blended experience, composed of a game and story that encouraged children to follow the canonical trajectory. To enhance the motivation to engage, a child-centred and informed three act character-based narrative was blended with the most successful game used by cultural and heritage providers, the treasure hunt.

Orchestration or the motivation to change locations was basically a sequential clue-based mystery, with the clues held in the dialogue of the characters. In orchestrating the children, the companion character, Brownie also reinforced the canonical trajectory. In the storyworld, the children are searching for the magical gold, following the clues get them to it. To access the clues in both experiences, the child has to go to a physical location.

In the mixed reality class experience, the children were either in the real or the virtual, with the two realities distinct and separate. In supporting the transition from one reality to another, we aimed to mitigate the risk of discontinuity by integrating transitions at major plot points.

Using the super-villain trope, the narrative was straightforward and follows the three-act structure of set-up, confrontation and resolution. Initially, children are meeting characters and solving the puzzle, when unexpectedly at the mid-point of Act 2, confrontation and dramatic tension happens. The only way to escape Brian is to change realities.

No child raised any queries as to why they were changing reality, they knew - the villain was looking for them. All children were sufficiently immersed in the narrative to understand and participate in the transitions. Using a major plot point to change realities did smooth the transition. This became part of the story, blended in as a reaction to the supervillain and the ongoing need to help the creatures. The transition thus becomes congruent with user expectations with the change in role and environment having sense within the narrative experience and the children's role within it.

In creating the mobile game, we repurposed the assets. However, whilst we used the same set, characters and story, the mixed reality and mobile game differed. In the mobile game, individual interaction was with a single device in comparison to the collaborative, multi-device approach used in the class mixed reality. In the mobile game, the focus was not on the dramatic transition from real to virtual, but rather the blended use of virtual within real.

Again, the narrative and interaction requirements were designed to underpin the transitions from real to virtual. In the mobile game, the presence of a clue (e.g. a character dialogue) is signposted by characters announcing themselves with an audio signature. This signpost, reinforces the narrative, highlighting that this is where a character lives and thus, that the child can interact with them to find out more information. Requiring that the phone is in sleep mode except when interacting with the characters in their locations, reinforces the transition between realities and the canonical trajectory, supporting the user in moving to and from the virtual and real, to engage with the character (on phone) and to find the next character (in the real).

The mobile game required some technical development and minor additions, for example, GPS signals and the character audio signatures. Small dialogue changes were also needed in relation to the new trajectory. However, with minor changes, a very different experience was achieved.

\section{CONCLUSION}

Our imperative is to design experiences that complement rather than distract from the physical spaces in which we work. This approach specifically considers the digital/physical blend before designing for either of these environments in isolation.

By working in close partnership with children we have built a mixed reality game that appeals to other children. Our partners have directly influenced the characters and the narrative as well as providing all audio. Using concepts of transitions and structure we have constructed an enjoyable complimentary activity that adds value to visiting Jupiter Artland in the real world

We have highlighted a set of narrative tools and a participatory approach that can be used to effectively construct mixed reality games on site. We have employed our game in a manner that encourages engagement with our virtual version of Jupiter Artland when remote from site. These narrative tools aid us in colluding with our target audience in pretence and make-believe play.

In comparison to the real, virtual Jupiter Artland lacks resolution, diversity and graphical interest, with the pixelated blocks of Minecraft providing limited visual realism. Why then, would a child choose to interact in virtual Jupiter Artland if they were already in the real place? The simplest answer is because it is fun, that it adds value and augments reality by integrating play, make-believe and pretence, activities children (and many adults) enjoy. 


\section{ACKNOWLEDGEMENTS}

We are indebted to our partner class and their teacher.

This work would not have been possible without the generosity of Jupiter Artland and their learning foundation. Grateful thanks go to Helena BarrettDuncan and Aga Banach.

This work was partially supported by the AHRC funded Creative Fuse North East project.

\section{REFERENCES}

Benford, S., Giannachi, G., Koleva, B., \& Rodden, T. (2009). From Interaction to Trajectories: Designing Coherent Journeys Through User Experiences. In Proceedings of the SIGCHI Conference on Human Factors in Computing Systems (pp. 709-718). New York, NY, USA: ACM. https://doi.org/10.1145/1518701.1518812

Benyon, D. (2012). Presence in Blended Spaces. Interacting with Computers., 24(4), 219-226. https://doi.org/10.1016/j.intcom.2012.04.005

Benyon, D., Mival, O., \& Ayan, S. (2012). Designing Blended Spaces. In Proceedings of the 26th Annual BCS Interaction Specialist Group Conference on People and Computers (pp. 398-403). Swinton, UK, UK: British Computer Society. Retrieved from http://dl.acm.org/citation.cfm?id=2377916.23779 74

Curious Directive. (2018). FROGMAN - A Groundbreaking VR/Theatre Hybrid. Retrieved 13 April 2018, from https://www.curiousdirective.com/frogmantour/

Davis, T. C. (2005). Do You Believe in Fairies?: The Hiss of Dramatic License. Theatre Journal, $57(1)$, $57-81$. https://doi.org/10.1353/tj.2005.0007

Druin, A. (2002). The role of children in the design of new technology. Behaviour and Information Technology, 21(1), 1-25. https://doi.org/10.1080/01449290110108659

European Commission. (2016). Cultural heritage Digitisation, online accessibility and digital preservation - Progress Report 2013-15. Directorate-General for Communications Networks, Content and Technology.

Field, S. (1982). The Screenwriter's Workbook. London: Random House.
Flint, T, Turner, P, Banach,A (2016) The Ensoulment of Virtual Space Minecraft as a tool for Engaging With a Sculpture Park. IDC '16 Proceedings of the The 15th International Conference on Interaction Design and Children, 680-683. doi:10.1145/2930674.2938613. ISBN 9781450343138

Fosh, L., Lorenz, K., Benford, S., \& Koleva, B. (2015). Personal and social? Designing personalised experiences for groups in museums. Presented at the MW2015: Museums and the Web 2015. Retrieved from https://mw2015.museumsandtheweb.com/paper/ personal-and-social-designing-personalisedexperiences-for-groups-in-museums/

Freeman, D. (2004). Creating Emotion in Games. San Francisco CA: New Riders.

O'Keefe, B., Benyon, D., Chandwani, G. \& Menon, M. (2013). A Blended Space for Heritage Storytelling. Proceedings of the 28th International BCS Human Computer Interaction Conference $(\mathrm{HCl}$ 2014) Southport UK doi:10.14236/ewic/hci2014.10

Örnerbring, H. (2007). Alternate Reality Gaming and Convergence Culture. International Journal of Cultural Studies, 10(4), 445-462.

Roussou, M. (2004). Learning by Doing and Learning Through Play: An Exploration of Interactivity in Virtual Environments for Children. Comput. Entertain., 2(1), 10-10. https://doi.org/10.1145/973801.973818

Shrikant, A. (2017, May 10). 10 Museum Apps to Make Your Family's Visit Easier. Retrieved 27 January 2018, from https://www.mommynearest.com/article/10museum-apps-to-make-your-familys-visit-easier

Turner, P., Hetherington, R., Turner, S., \& Kosek, M. (2015). The limits of pretending. Digital Creativity, 26(3-4), 304-317. https://doi.org/10.1080/14626268.2015.1091778

Turner, S., Huang, C.-W., Burrows, L., \& Turner, P. (2016). Make-Believing Virtual Realities. In Digital Make-Believe (pp. 27-47). Springer, Cham. https://doi.org/10.1007/978-3-319-295534_3

Walton, K. (1990). Mimesis as make-believe: on the foundations of the representational arts. Cambridge MA: Harvard University Press.

Winnicott, D. (1982). Playing and Reality. London: Routledge. 